like that. But I said "Why shouldn't I go out, my husband trusts me."

Even the little missionary children have their part in this great work of winning Islam for Christ. Their clean skin and clothes are noticed at once and as the women see them oftener they see the love which bubbles up out of their eyes and hearts whose source is in their Christian birth.

B. A. Mrtrea.

Kuweit, Arabia.

\title{
V. Tabriz, Persia
}

The first Turk who ever spoke to me of his wife by her name, was Mousa, servant in a missionary home, who said, "when I was a Moslem, I used to pick up a stick of wood or anything handy and hit Fatima over the head, but now I am a Christian, I can't do that." His naming her struck me, as a Moslem generally calls his wife " $M y$ child, my house, or the mother of such a child." The children do not say mother and father, but the master, the mistress, the older brother and the great sister. They appear to be ashamed of the natural relations of life.

The family life of even nominal Christians is much above that of the Moslems, and where the two religions are brought into close relation it always makes a deep impression on the latter people. Much more is this the case where they see genuine Christianity, whether in the case of missionaries or people of the country.

The women envy the security and honor of the Christian wife. One said, "Your prophet has done well by you, but ours has done very badly; when we meet I shall have words with him." A young woman of a noble and wealthy family said, "You ask me if I fear my husband will divorce me, or take another wife? I think not; he is old and sickly; it does not seem likely"; then she added thoughtfully, "But we never know."

The servants of Christian families get to be ashamed of polygamy and divorce; in one clan, with which I am familiar, many of whose men have served in missionary 
homes, these practices are rare and a woman has been heard to pride herself on the security of the wives of that connection.

One of the men, having lost his wife, was asked about a second marriage; he replied, with a reproachful look, "Lady, I do not expect to marry again; I am a Christian." He was told death had dissolved his contract, but it was not till some years after, that he took a second wife.

Another of their men names as one of the chief attractions of heaven, the fact that "there they neither marry nor are given in marriage."

A. is a Turkish villager, who read a New Testament and was converted without contact with other Christians. When a missionary came into his neighborhood he made himself known and asked advice as to what he should do. He was told to stay where he was till his life should be endangered. When his wife was taken from him and given to another man and the rope was placed on his neck to hang him, he fled to a neighboring Christian country, where he found work and safety. There I saw him some years ago, working as a gardener. Being aware of some matrimonial projects which were on foot for this eligible young man, I questioned him on the subject. He said he had no intention of marrying, as he feared he might not find the right kind of a wife and he did not wish one who would prove a hindrance and clog to his spiritual life. He modestly remarked, "It is not that I have not had offers; some of the best men in our church here have spoken to me for their girls, but it does not seem best to me to marry." I believe also, as his Moslem wife was still living, he did not consider himself free to contract a marriage in her lifetime. There had been no children and her early death released him from this scruple.

Five years later, passing through his city, I went in the early morning, to his little home. where he cordially invited me to take breakfast.

Presently a bright, cheerful young woman ran in, embraced and kissed me, while A. introduced her as his German wife, Mariam, saying, "The Lord chose and gave her to me; we are both devoted to Him and of the same 
mind about serving Him." He took a Turkish Bible and she a Russian one, reading alternately and he prayed; then we took breakfast together.

Returning from Europe a few months later, I again visited the home; the little wife was not there, but in a hospital, as their first child had come to them two or three days before. The father was to go on Sunday to see his baby boy, and asked me to accompany him. When we reached Mariam's white bed, before looking at the child, or even alluding to it, he stooped down, kissed his wife and expressed his joy at her safety, as any man might, who had behind him centuries of Christian ancestors and years of Christian training.

They told me they had dedicated this first-born child to the work of the Lord, hoping and praying he might become an evangelist to Moslems. As we left the building, his pride and delight broke out: "Did you ever see such a pretty little baby of this age?" This is sometimes an embarrassing question, but I could truly say the baby was pretty. Is not this a lesson for those who think we cannot expect much in the way of results till we get the second and third generations of Christian converts?

So also of a converted Kurd, who had been a fanatical hater of Christ and Christians. His heart was set on a girl of Oriental Christian parentage, but the course of true love was far from running smoothly; she was denied him and hope deferred made his heart sick. A missionary imprudently remarked, "He will soon get over it; no Oriental can care long for that homely girl." This remark was repeated to M. S.; he replied with dignity, "I am not influenced by the physical attractions of $R$. It is her beautiful soul that I love." One is glad to say that God gave him the desire of his heart, and another Christian home was established in this country, which stands in such need of them.

A Christian Sayyid, whose wife was bitterly opposed to his belief, once called together the little group of believers to which he belonged, for an all night prayermeeting, that his wife might be converted. Her heart was changed, and peace reigned in their home. One morning he came to 
the school where he gave lessons, but so sad that one of the ladies asked him what was the matter. He replied that in the morning he had been angry with his wife, and had spoken to her very unkindly. " $O$, you can soon make that right; tell her so and ask her forgiveness, which she is sure to grant." "I have already done so and she has forgiven me, but $I$ cannot forgive myself for acting in a manner so unworthy of the name of Christian."

We thank our Lord for these "sweet first fruits," which are an earnest of what it will some day mean for "the wilderness to blossom as the rose."

G. Y. Hollidit.

Tabriz, Persia. 